\title{
THE EFFECT OF CORPORATE SOCIAL RESPONSIBILITY DISCLOSURES AND FINANCIAL INFORMATION ON ABNORMAL RETURN (Empirical Study on Food and Beverage Sub-sector Manufacturing Companies Listed on Indonesian Stock Exchange in 2013-2017)
}

\author{
Suroto \\ Economic and Business Faculty 17 Agustus 1945 University (UNTAG) of Semarang \\ Email : srt.smpg@yahoo.co.id \\ Ch. Asta Nugraha \\ Economic and Business Faculty 17 Agustus 1945 University (UNTAG) of Semarang \\ Email : chastanugraha@gmail.com
}

Received: December 2018; Accepted: January 2019; Available online: January 2019

\begin{abstract}
This study aims to find the empirical evidence regard to the effect of corporate social disclosure responsibility and financial information proxied by accounting profits and return on assets on abnormal returns in food and beverage sub-sector manufacturing companies. The population in this study are all companies whose the stocks incorporated consistently in food and beverage sub-sector during 2013-2017. This study uses secondary data in the form of annual reports and panel data regression with a random effect model is applied to test the hypotheses. The results of this study shows that disclosure of corporate social responsibility has negative but insignificant effect on abnormal return, accounting earnings has negative but insignificant effect on abnormal return and return on assets have a positive and significant effect on abnormal returns.
\end{abstract}

Keywords: corporate social responsibility, accounting profit, return on assets, abnormal return.

\begin{abstract}
Abstrak
Penelitian ini bertujuan untuk menemukan bukti empiris pengaruh pengungkapan corporate social responsibility dan informasi keuangan yang diproksi dengan laba akuntansi dan return on assets terhadap abnormal return pada perusahaan manufaktur sub sektor makanan dan minuman. Populasi dalam penelitian ini adalah seluruh perusahaan yang sahamnya konsisten tergabung dalam sub sektor makanan dan minuman periode 2013-2017. Penelitian ini menggunakan data sekunder berupa laporan tahunan dan regresi data panel dengan random effect model yang dipergunakan untuk menguji hipotesis. Hasil penelitian ini menunjukkan bahwa pengungkapan corporate social responsibility berpengaruh negatif tidak signifikan terhadap abnormal return, laba akuntansi berpengaruh negatif tidak signifikan terhadap abnormal return dan return on assets berpengaruh positif dan signifikan terhadap abnormal return.
\end{abstract}

Kata kunci: corporate social responsibility, laba akuntansi, return on assets, dan abnormal return.

How to Cite: Suroto, \& Nugraha, C. A. (2019). Effect of Corporate Social Responsibility Disclosures and Financial Information Against Abnormal Return (Empirical Study on Food and Beverage Sub-sector Manufacturing Companies Listed on Indonesian Stock Exchange in 2013-2017). Media Ekonomi dan Manajemen, 34(1), 102-115. 


\section{INTRODUCTION}

Capital markets are said to have economic functions because capital markets provide facilities to parties who have excess funds and with those who need funds. The existence of a capital market is that the parties who have excess funds can invest these funds in hopeof obtaining returns, while those who need funds can use these funds for investment purposes without waiting for the availability of funds from the company's operations. The capital market is said to have a financial function, because the capital market provides the possibility and opportunity to obtain a return for the owner of the fund based on the characteristics of the chosen investment (Darmadji and Hendi, 2011).

The market reaction to information to achieve a new equilibrium price is important. If the market reaction is fast and accurate to achieve a new equilibrium price, which fully reflects the information available, then this market condition is called an efficient market (Hartono, 2009), while Husnan (2009) stated that an efficient capital market is a market which the price securities have reflected all relevant information. The efficient market is tested by looking at the abnormal returns that occur. The market is said to be inefficient if one or several market players can enjoy abnormal returns for a long period of time. The difference between the expected return and the realized return is called abnormal return. Abnormal returns will be positive if the realized return is bigger than the expected return. Conversely, the abnormal return will be negative if the realized return is smaller than the expected return (Hartono, 2009).
To obtain the expected return, the investors need various information as the basis for decision making, both in the form of financial and non-financial performance information disclosed by companies that react to investors and reflect in abnormal returns so it will improve the welfare of the investors (Amalia, et al, 2014). Disclosure of corporate social responsibility and financial information in annual reports are expected as good information for the market and responded by the investors (Listiyanti, 2011).

There were many researches have tested the disclosure variables of corporate social responsibility, accounting earnings and return on assets that are associated with abnormal returns and it showed many different results. The main factor that differentiates this research from the previous research is in the estimation and selection of panel data regression models. Previous research used the Ordinary Least Square approach, while this study used Generalized Least Square. The diversity of the results of previous study as shown in Table 1.

The diversity results from the several studies on abnormal returns showed an interesting phenomenon and it needs to be re-tested. Based on that situation this research was conducted with the aim of finding empirical evidence of the effect of corporate social responsibility disclosure, financial information proxied by accounting profit and re-on assets on abnormal returns in food and beverage sub-sector manufacturing companies listed on Indonesia Stock Exchange in 20132017. 
Table 1. Research Gap

\begin{tabular}{|c|c|c|}
\hline Research Gap & Research result & Researcher \\
\hline \multirow[t]{2}{*}{$\begin{array}{l}\text { There are different results of } \\
\text { the study on the effect of CSR } \\
\text { disclosure on abnormal returns }\end{array}$} & $\begin{array}{l}\text { Positive and } \\
\text { significant }\end{array}$ & $\begin{array}{l}\text { Cheng and Christiawan (2011), } \\
\text { Anugrawati and Wahidahwati } \\
\text { (2015), Amalia, et al (2014) }\end{array}$ \\
\hline & $\begin{array}{l}\text { Negative is not } \\
\text { significant }\end{array}$ & Alawiyah (2017) \\
\hline \multirow{2}{*}{$\begin{array}{l}\text { There are different results of } \\
\text { the study on the effect of } \\
\text { accounting earnings on } \\
\text { abnormal returns }\end{array}$} & $\begin{array}{l}\text { Positive and } \\
\text { significant }\end{array}$ & $\begin{array}{l}\text { Faizah and Priyadi (2014), } \\
\text { Djam'an, et al (2011) }\end{array}$ \\
\hline & $\begin{array}{l}\text { Negative is not } \\
\text { significant }\end{array}$ & Hutomo (2013) \\
\hline \multirow{2}{*}{$\begin{array}{l}\text { There are different results of } \\
\text { the study on the effect of } \\
\text { return on assets on abnormal } \\
\text { returns }\end{array}$} & $\begin{array}{l}\text { Positive and } \\
\text { significant }\end{array}$ & Syauta and Widjaja (2009) \\
\hline & $\begin{array}{l}\text { Positive is not } \\
\text { significant }\end{array}$ & Alawiyah (2017) \\
\hline
\end{tabular}

Source: Extracted from various journals

\section{THEORETICAL REVIEW AND HYPOTHESES \\ Stakeholder Theory}

Stakeholder Theory is a theory which stated that a company is not an entity that only operates for its own sake, but must provide benefits to all its stakeholders (Ghozali and Chariri, 2007). Stakeholder Theory assumed that the existence of a company is determined by stakeholders. The company tried to find the justification from stakeholders in carrying out the company's operations. The stronger the position of stakeholders, the stronger the tendency of companies to adapt themselves as the wishes of stakeholders (Indrawati, 2011).

By knowing what stakeholders want, managers can form a flexible corporate strategy. The strategy that is not only can accommodate all stakeholders' interests, but also the company's final goals (Listiyanti, 2011). The corps strategy is to implement corporate social responsibility and financial reporting programs and disclose them in the annual report. Social disclosure and financial information can be considered as a form of dialogue between management and stakeholders. It is really important to be done because the investors as stakeholders need to evaluate the extent in which the company has carried out its role as the wishes of stakeholders.

\section{Signaling Theory}

Signaling theory is a theory that explained the information signals needed by investors to consider and determine whether investors will invest or not in the company involved (Indrawati, 2009). Signaling theory is rooted in pragmatic accounting theory that observes the influence of information toward the information user behavior changing (Suwardjono, 2005).

Signaling theory suggested how a company should provide signals to users of financial and non-financial reports. This signal is in the form of information about what management has done to realize the owner's desires, namely maximizing their profits. Signals can be in the form of promotions or other information which stated that the company is better than other companies (Falichin, 2010).

Based on Signaling theory, the company's social and financial reporting activities in the annual report give information to investors about the prospect of substantial future returns. Disclosure of corporate social responsibility and financial reports that are exact and appropriate with stakeholder expectations 
is a good signal given by management to the public and it shows that the company has good prospects in the future and ensures the sustainability of the company's business. The company discloses corporate social responsibility in hope that it can improve the reputation and value of the company through increasing stock prices (Apriwandi and Pratama, 2014).

\section{Efficient Market Theory}

According to Tandelilin (2001) efficient market is the market where all prices securities traded reflect all available information. Available information includes past information (such as last year's company profits), current information (for example this year's dividend increase plan), and the information that is opinion or rational opinion which circulate in the market that can affect price changes. If the market is efficient and all available information can be obtained by all parties easily and with a low cost so a balance price will be formed and there is no investor can obtain an abnormal return by utilizing the information he has.

\section{Abnormal Return (AR)}

Abnormal return is one indicator that is used to see the recently market situation. Information can be said to have value for investors if the information give a reaction to conduct transactions on the capital market (Hartono, 2009). The investor's trust aspect is one of the most influential aspects in the stock market. Therefore, an announcement or disclosure will be responded by investors in various ways.

Hartono (2009), stated that abnormal returns are the difference between realized returns and expected returns. Abnormal returns will be positive if the return obtained is bigger than the expected return or calculated return, while the abnormal return will be negative if the return obtained is smaller than the expected return or the calculated return.
Corporate Social Responsibility (CSR) Cheng and Christiawan (2011), emphasized that corporate social responsibility is an organization's responsibility for the impacts of its decisions and activities on society and the environment which are manifested in the form of transparent and ethical behavior that is in line with sustainable development and community welfare; consideration of stakeholder expectations, in line with established law and norms of international behavior and integrity with the overall organization.

It is expected that investors consider the information on corporate social responsibility disclosed in the company's annual report. If the corporate social information responsibility is taken as the consideration by investors in decision making which followed by the stock purchases increased, it means that there is an increase in stock prices that exceed the estimated return by investors. It can be concluded that corporate information social responsibility is information that give added value for the investors and causes abnormal stock returns. .

\section{Accounting Profit (LAK)}

Harahap (2009), stated that what is meant by accounting profit is excess income above costs during one accounting period. Profit is often used as a measurement of company performance. A company has good financial performance can be measured through profits earned each year, especially if the profits earned each year have increased. Therefore, high profits affect dividend distribution by issuer companies. It attracted the investors' attention to invest in that company.

High profits will be the hope of many parties, such as: 1) managers in getting high bonuses, 2) dividend distribution, 3) high employee compensation, 4) creditors in terms of smooth interest receipts and loan principal, 5) government in terms of obtaining high tax returns, etc. (Arfan, 2006). 


\section{Return on Assets (ROA)}

Sartono (2001) stated that return on assets is used to measure how a company's ability to get profits or benefits, both in relationship with sales, assets and profits for own capital. Prastowo and Yulianty (2005) suggested that return on assets is the ability of companies to use their assets to earn profits, while Syauta and Widjaja (2009) stated that return on assets measures how efficient the profits can be obtained from assets used or owned by the company.

Return on Assets can be used as an indicator of corporate earnings power which reflects the management performance in using all assets owned. The high and low Return On Assets depend on the management of company assets by management which describes the efficiency of the company's operations.

\section{Development of Hypotheses}

The effect of CSR disclosure on abnormal returns.

Disclosure of corporate social responsibility is expected to have information content, so that the market or investor will react after the announcement is received. This positive signal is expected to generate a positive response from the market. Hartono (2009) stated that investor reactions can be measured using abnormal returns. There are various reaction from investors toward the information. Information that provide trust in the prospects of a good company in the future will be responded to with an increase in the stock prices. Thus, it can be concluded that the disclosure of corporate social responsibility information in the company's annual report has a positive effect on abnormal return.

Research by Cheng and Christiawan (2011) found the evidence that disclosure of corporate social responsibility has a positive and significant effect on abnormal return. The results of this study are supported by Sayekti and Wondabio (2007) who concluded that disclosure of corporate social responsibility has a positive and significant impact on market reactions (abnormal return). Likewise, Nurdin and Cahyandito (2006) research showed that disclosure of social and environmental themes in the annual report has a significant effect on investor reactions as measured by abnormal returns. Based on the description above, the first hypothesis can be formulated as follows:

$\mathrm{H}_{1}$ : There is a positive and significant effect of disclosure of corporate social responsibility to abnormal returns.

\section{The effect of accounting profit on abnormal return.}

Companies that earn profits will be said to have performed financially well and will affect the expectations of investors to obtain profit sharing in the form of dividends. Furthermore, these expectations will affect investor behavior in conducting transactions on the exchange. Theoretically, if the company gets bigger profits, then the company will be able to distribute dividends that are getting bigger and will have a positive effect on the stock returns that investors will expect. It has an impact on abnormal returns.

The results of Djaman's research, et all (2011) proved that there is a positive and significant effect of accounting earnings on abnormal returns. This indicates that information about company profits is still widely used by investors in assessing company performance, even though there is other information. It also shows that high profitability gives a positive signal about the growth of the company value in the future. Based on the description above, the second hypothesis can be formulated as follows:

$\mathrm{H}_{2}$ : There is a positive and significant effect of accounting earnings on abnormal returns. 


\section{Effect of return on assets on abnormal return.}

Return on Assets has a positive relationship with stock prices, the higher return on assets of the company, the better the company uses its assets to earn profits, by increasing return on assets the company's profitability will be increased (Arista, 2012). It makes investors interested in buying company stocks and has an impact on stock prices which are getting increased and followed by the high stock returns. Finally, the market will respond positively as reflected in abnormal returns.
The results of previous study on the effect of return on assets on abnormal returns have been investigated by Syauta and Widjaja (2009). They proved that return on assets has a positive and significant effect on abnormal returns. Based on the description above, the third hypothesis can be formulated as follows:

$\mathrm{H}_{3}$ : There is a positive and significant effect of return on assets on abnormal return.

Based on the study of theory and previous research, the research model can be seen in the following Figure 1.

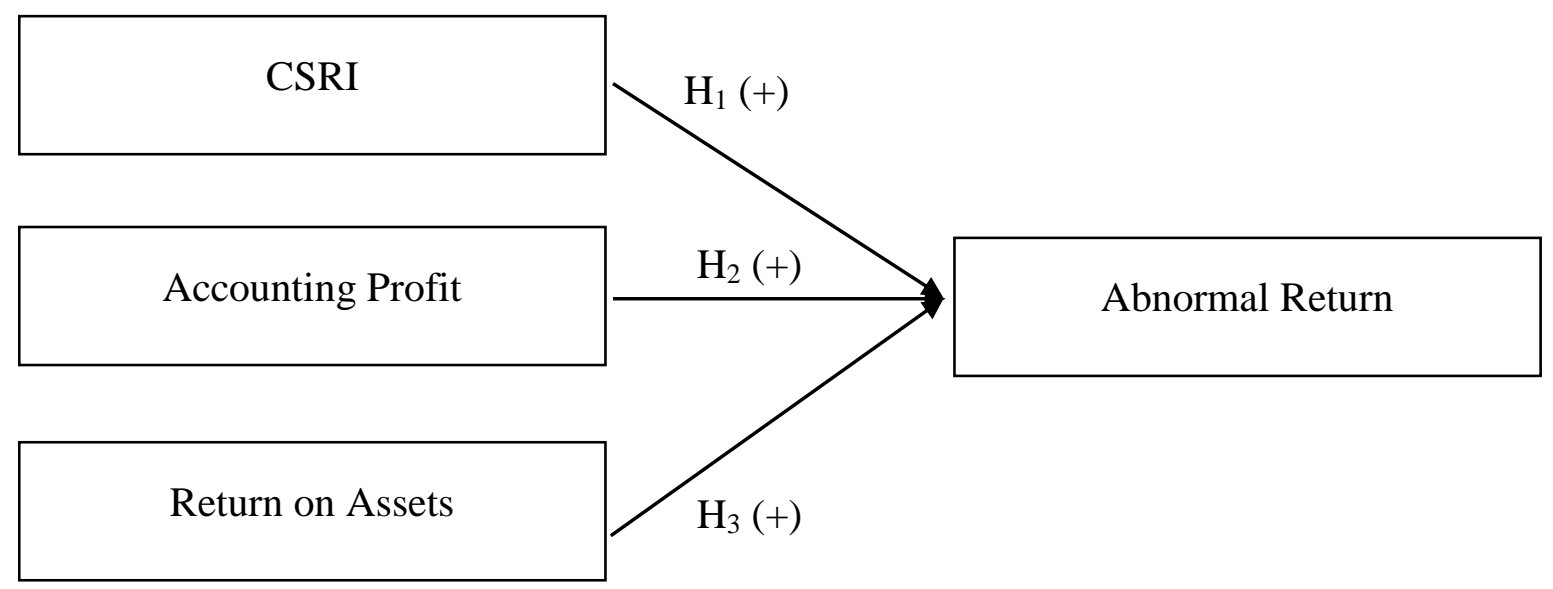

Figure 1. Research Model

\section{RESEARCH METHODS Population and Samples}

This research includes in population research, namely research that examines all the elements contained in the population, or also referred to as census research (Arikunto, 2006). The population in this study were all companies whose stocks were incorporated in the food and beverage sub-sector in 2013 - 2017 as many as 18 companies, while the subjects or units of analysis in this study were audited annual reports of companies selected as populations.
Determination of stocks in the population will be examined based on the population criteria, namely companies whose stocks consistently incorporate in the food and beverage sub-sector and regularly publish the annual reports that contain sustainability reports and submitted to Indonesia Stock Exchange as many as 8 companies. The selection process of the population according to the established criteria is presented in the following Table 2. 
Table 2. The Population Selection Selection Research Process

\begin{tabular}{clc}
\hline No & \multicolumn{1}{c}{ Population Criteria } & Number of Issuers \\
\hline 1 & $\begin{array}{l}\text { Companies incorporate in the food and beverage } \\
\text { sub-sector in 20013 - 2017 } \\
\text { Companies that do not regularly publish the }\end{array}$ & 18 \\
2 & $\begin{array}{l}\text { sustainability reports in 20013 - 2017 } \\
\text { Companies that regularly publish sustainability } \\
\text { reports in 2013 - 2017 }\end{array}$ & 8 \\
4 & Number of observations (8 x 5) & 40 \\
\hline
\end{tabular}

Source: IDX 2013-2017

\section{Method of Collecting Data}

This study used secondary data, as follows:

1. Data on corporate CSR disclosures in annual reports that are accessed through IDX's official website at www.idx.co.id.

2. Data on stock closing prices and daily CSPI are accessed through www.idx.co.id.

3. Summary of company performance data accessed through the official IDX website at www.idx.co.id.

\section{Operational Definition and Variable Measurement}

The operational definitions of each variable in this study are as follows:

1. Cummulative Abnormal Return (CAR) is an accumulation of abnormal returns. Abnormal return is the difference between the level of actual profit and the expected level of profit. Cumulative Abnormal Return (CAR) calculation formula:

$\mathrm{CAR}_{\mathrm{i}, \mathrm{t}}=\Sigma \mathrm{AR}_{\mathrm{i}, \mathrm{t}}$

Where:

$$
\begin{aligned}
& \mathrm{AR}_{\mathrm{i}, \mathrm{t}}=\mathrm{R}_{\mathrm{i}, \mathrm{t}}-\mathrm{E}\left(\mathrm{R}_{\mathrm{i}, \mathrm{t}}\right) \\
& \mathrm{R}_{\mathrm{i}, \mathrm{t}}=\frac{\mathrm{P}_{\mathrm{i}, \mathrm{t}}-\mathrm{P}_{\mathrm{i}, \mathrm{t}-1}}{\mathrm{P}_{\mathrm{i}, \mathrm{t}-1}}
\end{aligned}
$$

In this study, the expected return is calculated using the Market-adjusted model, with the equation:

$$
\mathrm{R}_{\mathrm{m}, \mathrm{t}}=\frac{\mathrm{IHSG}_{\mathrm{t}}-\mathrm{IHSG}_{\mathrm{t}-1}}{\mathrm{IHSG}_{\mathrm{t}-1}}
$$

2. The Corporate Social Responsibility Index (CSRI) is a corporate social responsibility disclosure index calculated based on the number of CSR disclosure items disclosed by the company. The disclosure index is determined by the tabulation technique for each company according to the list of social disclosures. The list of corporate social responsibility disclosures is divided into seven categories, namely: environment, energy, health and safety of workers, others labor, products, community and public involvement. CSRI calculation formula: $\mathrm{CSRI}_{\mathrm{j}}=\frac{\sum \mathrm{Xij}}{\mathrm{nj}}$

Where:

$\mathrm{CSRI}_{\mathrm{j}}$ : Corporate Social Responsibility Index of the company $\mathrm{j}$

$\mathrm{X}_{\mathrm{ij}}$ : The number of CSR disclosure items for companies $\mathrm{j}, \mathrm{nj}=91$

$\mathrm{n}_{\mathrm{j}} \quad: 1$ if item $\mathrm{i}$ is disclosed; 0 if item $i$ is not disclosed

Thus, $0 \leq \mathrm{CSRDIj} \leq 1$

3. Accounting profit (LAK) according to Muqodim (2005) in accounting profit there are various basic components such as gross profit, operating profit, profit before tax and net income. In this study accounting profit is proxied from net income, a summary of the net results of business operations in a certain period.

4. Return On Assets (ROA) is one of the profitability ratios that compares between earning after tax and total assets. ROA calculation formula:

ROA $=\frac{\text { Earning After Tax }}{\text { Total Assets }}$ 


\section{RESEARCH RESULTS AND DISCUS- SION}

\section{Research Result Analysis}

In order to test the hypothesis, this study used a panel data regression analysis and a significant level of $5 \%(\alpha=0.05)$ with rock program eviews 10 . Regression of panel data was chosen as an analysis tool because the data in this study is a combination of time series data and data cross section and dependent variable scale ratio, and its ability to show the influence of a variable on other variables, namely CSRI $\left(\mathrm{X}_{1}\right)$, LAK $\left(\mathrm{X}_{2}\right)$ and ROA $\left(\mathrm{X}_{3}\right)$ on CAR (Y) in companies that consistently incorporated in the food and beverage subsector period of 2013 - 2017.

The panel data regression model used is as follows:

$$
\begin{array}{ll}
\mathrm{Y}=\alpha+\beta_{1} \mathrm{X}_{1}+\beta_{2} \mathrm{X}_{2}+\beta_{3} \mathrm{X}_{3}+\mathrm{e} \ldots \ldots .(1) \\
\text { Where : } \\
\mathrm{Y} \quad \text { : Cummulative Abnormal Return } \\
\alpha \quad: \text { Constants } \\
\beta_{1} \beta_{2} \beta_{3}: \text { Regression Coefficient } \\
\mathrm{X}_{1} \quad \text { : CorporateSosial Reponsibility } \\
\quad \quad \text { Index } \\
\mathrm{X}_{2} \quad \text { : Accounting Profit } \\
\mathrm{X}_{3} \quad \text { : Return on Assets } \\
\mathrm{e} \quad: \text { Error / Confounding Variable }
\end{array}
$$

Before this model is used for hypothesis testing, firstly the estimation panel data regression model have been done, selection of panel data regression models, assumption test panel data regression model and test of goodness of fit. The model estimation results in Table 3 shows that the common effect model includes a panel data regression model that is not fit, because it has a prob-F bigger than $\alpha=0.05$.

The model selection test in Table 4 concludes that the Hausman test results $(0.368>\alpha=0.05)$ are consistent with the results of the lagrange multiplier test $(0.000<\alpha=0.05)$ so that the random effect model is the most appropriate model used in this study. Therefore, in the test panel data regression model does not require multicollinearity test, autocorrelation test and heteroscedasticity test because that panel data has a large variability and reduces the colonization between independent variables (Ghozali and Ratmono, 2017). Panel data is closer to the cross section data not the time series so it does not needautocorrelation test and random effect models using Generalize Least Square (GLS) which is one of the regression healing techniques and it does not need heteroscedasticity test as well (Iqbal, 2015).

The normality test in Table 5 shows that the residual data is normally distributed, because the Jarque-Bera value of 0.371 has a probability of 0.831 bigger than $\alpha=0.05$.

The results of the accuracy test modelin Table 6 shows that $\mathrm{R}$ squared of 0.196 has a significant level 0.047 smaller than $\alpha=0.05$, it can be concluded that random effect models show a fit model, because it can explain 19.60 percent of the variation in abnormal returns which measured with the commulative abnormal return from the average, while the rest of 80.40 percent is caused by other variables not included in the regression model.

Hypothesis test results in Table 6 shows that the first hypothesis $\left(\mathrm{H}_{1}\right)$ and second hypothesis $\left(\mathrm{H}_{2}\right)$ are rejected, because the CSRI and LAK beta coefficients each have a negative sign and the prob value is bigger than $\alpha=0.05$. It means that partially there is no significant negative effect of information disclosure on corporate social responsibility and accounting profit on abnormal returns. However, the third hypothesis $\left(\mathrm{H}_{3}\right)$ is accepted, because the ROA beta coefficient has a positive sign and the prob value is smaller than $\alpha=0.05$, which means there is a positive and significant effect of ROA on abnormal return.

\section{Discussion of Research Results \\ The Effect of Corporate Social Respon- sibility on Abnormal Return}

Based on the test results in Table 6, the CSRI beta coefficient value is -2.156 with a significant level of 0.694 bigger 
than $\alpha=0.05$, so that $\mathrm{H}_{1}$ which stated that disclosure of corporate social responsibility does not influence on abnormal return was rejected.

The results of this study proved that information disclosure of corporate social responsibility in the company's annual report cannot convince investors to be able to increase the company's stocks, therefore the information disclosure of corporate social responsibility is responded negatively and not used by investors in the investment decision making process. It is because of the low level of disclosure of corporate social responsibility of manufacturing companies that are the object of the research with an averageonly 43.60 percent or about 40 items from 91 items that must be disclosed. It is related to Indonesia's condition that the disclosure items of corporate social responsibility are still voluntary, so the company does not really focus on disclosing corporate social responsibility. In addition, investors may not believe in the disclosure of corporate social responsibility done by the company. It is because until now there are still many cases related to environmental, social and economic issues so investors consider that disclosure of corporate social responsibility is only a formality.

The high cost needed by the company to carry out corporate social responsibility programs can be also the reason for investors to be reluctant to invest, because of considering the costs for corporate social responsibility programs as a waste that actually reduces company profits. Another possibility is that investors react outside the research period, according to Jogiyanto (2009) the signal in the form of disclosure of corporate social responsibility provided by management is a very difficult signal to measure its economic value then the investors need longer time to react.

The results of this study are the same with the study of Alawiyah (2017). It was stated that disclosure of corporate social responsibility does not influence to abnormal returns and also in line with efficient market theory which explains if the market is efficient and all available information is easily to get to all parties and at a low cost, a balance price will be formed, therefore no investor can obtain an abnormal return by utilizing the information he has.

However, it is not consistent with the results of the research done by Cheng and Christiawan (2011), Anugrawati and Wahidahwati (2015), Amalia, Sarfan and Shabri (2014) which stated that disclosure of corporate social responsibility has a positive and significant effect on abnormal returns proxied with corporate social responsibility.

\section{Effect of Accounting Profit on Abnormal Return}

Based on the test results in Table 6, the beta coefficient is -1.417 with a significant level of 0.378 bigger than $\alpha=$ 0.05 , so $\mathrm{H}_{2}$ stated that accounting profit has a positive and significant effect on abnormal return was rejected. Negative direction indicates that the lower the accounting profit obtained by the company, the higher the abnormal return, on the contrary the higher the accounting profit obtained by the company, the lower the abnormal return. This negative direction is likely due to the loss of PSDN companies from 2014-2016.

The results of this study indicated that the disclosure of accounting profits made by companies in published annual reports has not been the center of investor attention in making investment decisions. It is caused by the possibility of PSDN companies' financial loss starting from 2014-2016. Beside that, it might be caused by investors assuming that earnings information is very vulnerable to earnings management practices. The phenomenon of the practice of earnings management has occurred in Indonesian capital market, especially for issuers manufacturing on Jakarta Stock Exchange (BAPEPAM, 2002). This results effect in the benefits of 
information contained in the profits will be reduced and information on the nominal value of earnings can not reflect the actual performance of the company.

Widyaningdyah (2001), proved that companies which are in danger of violating debt agreements tend to do earnings management by increasing profits in order to improve their bargaining position when renegotiating or as an attempt to go public to get fresh funds because of the difficulties in finding loan funds, while earnings management for companies that go public is conducted on the company's financial statement prospectus before the IPO in order to attract the investors to invest their financial capital. The results of this study are in accordance with Hutomo's (2013) study, stated that accounting earnings have a negative but not significant effect on proxied stock returns with abnormal returns. This research is also in line with efficient market theory that explains if the market is efficient and all available information can be obtained by all parties easily and at a low cost, a balance price will be formed, so that no investor can obtain abnormal returns by utilizing information he has.

However, unlike the research of Faizah and Priyadi (2014) and Djaman, et al (2011), stated that accounting profit has a significant positive effect on abnormal returns, this is because of the reliable accounting information and informative as a measurement of company performance.

\section{Effect of Return on Assets on Abnormal Return}

Based on the test results in Table 6, the beta coefficient is 1,630 with a significant level of 0.008 smaller than $\alpha=$ 0.05 , so that $\mathrm{H}_{3}$ which stated that return on assets has a positive and significant effect on abnormal returns was accepted. The positive direction of the beta coefficient is supported by a theory which explains that before conducting transactions in the capital market, investors first assess the issuer that published the stocks on the stock exchange. One aspect that becomes the assessment is the ability of issuers to produce the profits. If the ability of a company to produce profits is increasing, then the company's stock price will increase (Husnan, 2001).

The results of this study are consistent with the research of Syauta and Widjaja (2009), stated that the return on assets has a positive and significant effect on abnormal return. This research is also consistent with signaling theory because the information on return on assets disclosed in the summary of the company's financial performance provides a positive signal for investors in estimating returns. Apart from that the market also responds to return on assets as information that can change investors'trust so that it can influence stock returns which finally affectabnormal returns.

However, the research results are not consistent with efficient market theory, this is due to the information on return on assets in the publication of annual reports. The investors are able to obtain abnormal returns. The results of this study are also contrary to the results of Alawiyah (2017) research which stated that return on assets has a positive and insignificant effect on abnormal returns. This is because of information on return on assets in the publication of annual reports is not informative enough and it is no longer an investors' attention in making investment decisions.

\section{CONCLUSION}

The conclusions of the results of this study can be stated as follows: 1) disclosure of corporate social responsibility has negative but insignificant effect on abnormal return, 2) accounting profit has negative but insignificant effect on abnormal return, 3) return on assets has positive and significant effect on abnormal return. 


\section{SUGGESTION}

The suggestionss of the results of this study can be stated as follows: 1) the object of this study only used 8 companies with an observation period of 5 years so that for the next research it would be better to expand the object of the research such as all companies listed on the IDX and extend the observation period, 2) this study used the market-adjusted model, in estimating the expected rate of return. Therefore for further research it is recommended to try the mean-adjusted model and market model or use all three models, then the results of the calculation of the three models can be compared to find out the impact on the results of the study.

Table 3. Summary of Results of Estimated Panel Data Regression Models

\begin{tabular}{|c|c|c|c|c|c|c|}
\hline \multirow[t]{2}{*}{ Variable } & \multicolumn{2}{|c|}{ Common Effect } & \multicolumn{2}{|c|}{ Fixed Effect } & \multicolumn{2}{|c|}{ Random Effect } \\
\hline & Coefficient & Prob & Coefficient & Prob & Coefficient & Prob \\
\hline $\mathrm{C}$ & -1.757 & 0.277 & 2.655 & 0.348 & 1.085 & 0.639 \\
\hline CSRI & 5.361 & 0.182 & -5.816 & 0.387 & -2.156 & 0.694 \\
\hline LAK & -2.188 & 0.102 & -1.735 & 0.344 & -1.417 & 0.378 \\
\hline ROA & -1.556 & 0.870 & 3.175 & 0.004 & 1.630 & 0.008 \\
\hline CEKA-C & & & -0.851 & & -0.519 & \\
\hline ICBP-C & & & 0.449 & & 0.265 & \\
\hline INDF-C & & & 0.981 & & 0.532 & \\
\hline MLBI-C & & & -1.685 & & -1.472 & \\
\hline MYOR-C & & & -0.223 & & -0.294 & \\
\hline PSDN-C & & & -0.500 & & -0.479 & \\
\hline SKBM-C & & & 0.091 & & 0.360 & \\
\hline ULTJ-C & & & 1.738 & & 1.607 & \\
\hline R Squared & 0.0 & & 0.8 & & 0.1 & \\
\hline F-Statistic & 0.9 & & 18. & & 2.9 & \\
\hline Prob-F & 0.4 & & 0.0 & & 0.0 & \\
\hline
\end{tabular}

Source: Secondary Data Processed, 2018

Table 4. Summary of Test Results for Selection of Panel Data Regression Models

\begin{tabular}{llccl}
\hline \multicolumn{1}{c}{ Test } & \multicolumn{1}{c}{ Effects Test } & Statistic & Prob & Conslusion \\
\hline Chow & Cross-section Chi-square & 76.381 & 0.000 & Fixed effect \\
Hausman & Cross-section random & 3.155 & 0.368 & Random effect \\
Lagrange Multiplier & Cross-section and time & 43.669 & 0.000 & Random effect \\
\hline
\end{tabular}

Source: Secondary Data Processed, 2018

Table 5. Summary of Normality Test Results

\begin{tabular}{ccccc}
\hline Variabel & Skewness & Kurtosis & Jarque-Bera & Prob \\
\hline Standardized Residual & 0.187 & 2.712 & 0.371 & 0.831 \\
\hline
\end{tabular}

Source: Secondary Data Processed, 2018 
Table 6. Accuracy Test Results for Panel Data Regression

\begin{tabular}{lrrrr}
\hline Variable & Coefficient & Std.Error & t-Statistic & Prob \\
\hline C & 1.085 & 2.293 & 0.472 & 0.639 \\
CSRI & -2.156 & 5.444 & -0.396 & 0.694 \\
LAK & -1.417 & 1.558 & -0.892 & 0.378 \\
ROA & 1.630 & 0.929 & 2.831 & 0.008 \\
Random Effects (Cross) & & & & \\
CEKA-C & -0.519 & & & \\
ICBP-C & 0.265 & & & \\
INDF-C & 0.532 & & & \\
MLBI-C & -1.472 & & & \\
MYOR-C & -0.294 & & & \\
PSDN-C & -0.479 & & & \\
SKBM-C & 0.360 & & & \\
ULTJ-C & 1.607 & & & \\
\hline R-squared & & 0.196 & Prob & \\
Adjusted R-squared & & 0.129 & (F-statistic) & \\
F-statistic & & & & \\
\hline
\end{tabular}

Dependent Variable: CAR

Source: Secondary Data Processed, 2018

\section{BIBLIOGRAPHY}

Alawiah, S. Z. (2017). Pengaruh Pengungkapan CSR dan Informasi Keuangan Terhadap Abnormal Return (Studi Empiris Pada Perusahaan Pertambangan dan Perusahaan Pertanian Yang Terdaftar di Bursa Efek Indonesia Pada Periode 2011-2015). Skripsi. Universitas Islam Negeri Syarif Hidayatullah, Jakarta.

Amalia, R., Arfan, M., \& Shabri., M. (2014). Pengaruh Laba, Pengungkapan Corporate Social Responsibility, Dan Profitabilitas Terhadap Abnormal Return Saham. Jurnal Akuntansi 3(1), 124-132.

Anugrawati, M. A., \& Wahidahwati. 2015. Pengaruh Pengungkapan Corporate Social Responsibility dan Informasi Keuangan Terhadap Abnormal Return. Jurnal Ilmu \& Riset Akuntansi, 4(6), 1-21.
Arfan, M. (2006). Pengaruh Arus Kas Bebas, Set Kesempatan Investasi dan Financial Leverage terhadap Managemen Laba: Studi pada Emiten Manufaktur di BEJ. Padjadjaran Bandung.

Arikunto,S. (2006). Prosedur Penelitian Suatu Pendekatan Praktik. Jakarta: Rineka Citra.

Arista, D., \& Astor. (2012). Analisis Faktor-faktor Yang Mempengaruhi Return Saham (Kasus Pada Perusahaan Manufaktur yang Go Public di BEI periode Tahun 20052009). Jurnal Ilmu Manajemen dan Akuntansi Terapan, 3(1), 1-5.

Cheng, M., \& Christiawan, Y. J. (2011). Pengaruh Pengungkapan Corporate Social Responsibility terhadap Abnormal Return. Jurnal Akuntansi dan Keuangan, 13(1), 24-36.

Darmadji, T. \& Hendi, M. F. (2011). Pasar Modal di Indonesia. Pendekataan Tanya Jawab. Edisi Pertama. Jakarta: Salemba Empat. 
Djam'an, N., Pagalung, G., \& Tawakkal. (2011). Pengaruh Informasi Laporan Arus Kas, Laba dan Ukuran Perusahaan terhadap Abnormal Return Saham. Jurnal Riset akuntansi Indonesia.

Faizah \& Priyadi, M. P. (2014). Pengaruh Pengungkapan Corporate Social Responsibilty Dan Informasi Keuangan Terhadap Abnormal Return. Jurnal Ilmu \& Riset Akuntansi, 3(2), 1-17.

Falichin, M. Z. M. (2010). Pengaruh Corporate Social Responsibility Disclosure terhadap Reaksi Investor dengan Environmental Performance Rating sebagai Variabel Moderasi. Skripsi. Universitas Diponegoro, Semarang.

Ghozali, I., \& Chariri, A. (2007). Teori akuntansi. Semarang: Badan Penerbit Universitas Diponegoro.

Ghozali, I., \& Ratmono, D. (2017). Analisis Multivariat dan Ekonometrika Teori. Konsep, dan Aplikasi dengan Eviews, 10. Edisi Kedua. Semarang: Badan Penerbit Universitas Diponegoro.

Harahap, S. S. (2009). Analitis Kritis Atas Laporan Keuangan. Jakarta: Raja Grafindo Persada.

Hartono, J. (2009). Teori Portofolio dan Analisis Investasi. Edisi Keenam. Yogyakarta: BPFE.

Husnan, S. (2009). Dasar-dasar Teori Portofolio dan Analisis Sekuritas. Edisi Keempat. Yogyakarta: UPP STIM YKPN.
Hutomo, P. (2013). Pengaruh Arus Kas Operasi dan Laba Akuntansi terhadap Return saham pada Perusahaan Manufaktur yang Terdaftar di BEI. Skripsi. Sekolah Tinggi Ilmu Ekonomi Perbanas, Surabaya.

Indrawati, N. (2009). Pengungkapan Corporate Social Responsibility (CSR) dalam Annual Report serta Pengaruh Political Visibility dan Economic Performance. Pekbis Jurnal, 1(1), 1-11.

Iqbal. (2015). Operasionalisasi Regresi Data Panel. https://dosen. perbanas.id/wp-content/uploads/ 2015/01/Operasionalisasi -RegresiData-Panel.pdf $11.04 \quad$ 17/12/2018. Pukul 11,15.

Listiyanti, A. (2011). Pengaruh Tanggungjawab Sosial Perusahaan terhadap Reaksi Investor (Studi pada Perusahaan Manufaktur yang Terdaftar di BEI periode tahun 2008- 2009), Skripsi. Universitas Dopinegoro, Semarang

Muqodim (2005). Teori Akuntansi. Edisi 1. Yogyakarta: Ekonesia FE UII.

Nurdin, E. \& Cahyandito, M. F. (2006). Pengaruh Kualitas Pengungkapan Sosial dan Lingkungan dalam Laporan Tahunan terhadap Reaksi Investor, Thesis. Universitas Padjajaran.

Prastowo, D., \& Yulianty, R. (2005). Analisis Laporan Keuangan Konsep dan Aplikasi, Yogyakarta: UPP AMP YKPN.

Sartono, R. A. (2001). Manajemen Keuangan (Teori dan Aplikasi). Edisi 4. Cetakan 1. Yogyakarta: BPFE. 
Sayekti, Y., \& Wondabio, L. S. (2007). Pengaruh CSR Disclosure terhadap Earning Response Coefficient. Simposium Nasional Akntansi $X$ Makasar. 26-28 Juli: 1-35.

Suwarjono. (2005). Teori Akuntansi. Edisi Ketiga. Yogyakarta: BPFE.

Syauta, R. C., \& Widjaja, I. (2009). Analisis Pengaruh Rasio ROA, LDR, NIM dan NPL Terhadap Abnormal Return Saham Perbankan Di Indonesia Pada Periode Sekitar Pengumuman Subprime Mortgage. Journal of Applied Finance and Accounting, 1(2), 351-367.

Tandelilin, E. (2001). Analisis Investasi dan Manajemen Portofolio. Yogyakarta: BPFE..

Widarjono, A. (2007). Ekonometrika: Teori dan Aplikasi Untuk Ekonomi dan Bisnis, Edisi Kedua. Yogyakarta: Ekonisia FE Universitas Islam Indonesia.

Widyaningdyah, A. U. (2001). Analisis Faktor-faktor Yang berpengaruh Terhadap Earnings Management Pada Perusahaan Go Public Di Indonesia. Akuntansi Dan Keuangan, 3(2), 89-101.

Yudiatmaja, F. (2013). Analisis Regresi Dengan Menggunakan Aplikasi Komputer Statistika SPSS. Jakarta: Gramedia Pustaka Utama. 